\title{
BOEKBESPREKINGS/BOOK REVIEWS
}

\author{
Memoirs of General Ben Bouwer \\ Argiefbewaarplekke, kopieregbiblioteke en ander \\ instansies wat historiese bronne bewaar is \\ gewoonlik in die groter stede gesentreer. Vir die \\ historikus wat nie in die stad woon waar die \\ dokumente wat hy benodig bewaar word nie, \\ skep dit 'n probleem. Gewoonlik selekteer so 'n \\ historikus dan 'n onderwerp waarvan die bronne \\ maklik bekombaar is.
}

In 'n poging om historici en ander belangstellendes tegemoet te kom, word oorspronklike bronne in boekvorm gepubliseer. Dit staan in die vaktaal as bronnepublikasies bekend. Op die wyse word die oorspronklike bron tot die beskikking van 'n wyer kring gestel. Die historikus kan dus ' $n$ reeks primêre bronne in sy eie studeerkamer versamel en hom die ongerief bespaar om na 'n bewaringsinstansie te gaan.

'n Bronnepublikasie bevat gewoonlik veel meer informasie as die oorspronklike bron omdat van die redakteur verwag word om die bron toeganklik of meer verstaanbaar te maak. Hierdie redigering vereis ' $n$ besondere kennis van die periode waaroor die bron handel en 'n buitengewone deursettingsvermoë.

Die Memoirs of General Ben Bouwer is die negende in 'n reeks bronnepublikasies oor die Anglo-Boereoorlog wat deur die Raad vir Geesteswetenskaplike Navorsing gepubliseer word. Die hoë standaard wat met die vorige agt publikasies gestel is, word met hierdie negende publikasie steeds volgehou.

Die Memoirs is in 'n gemaklike Engels geskrywe en lees soos 'n roman. Die trant van die Memoirs openbaar die karakter van generaal Ben Bouwer: ' $n$ man wat selfrespek en karakter hoër geag het as ' $n$ groot naam en roem. Nooit verval hy in kleinlikhede nie. Selfs die sensitiewe saak van oorlopers na die vyand en die veroordeling van Colyn behandel hy met simpatie.

Die grootste gedeelte van die boek handel oor Bouwer se aandeel in die Anglo-Boereoorlog. Met breë trekke raak hy ook aan die Rebellie. Hier veral is sy siening van Maritz baie insiggewend.

Hy veroordeel nie sy ou strydmakker omdat hulle in opponerende hoeke is nie, maar probeer verstaan. Trouens, hy wys daarop dat dit bloot pligsbesef en die feit dat hy aan die Unieverde- digingsmag verbonde was wat hom die Rebellie laat help onderdruk het.

Benewens Maritz laat Bouer ook die lig val op ander historiese figure soos Jan Smuts, onder wie se leiding hy die Kaapkolonie binnegeval het, Koos de la Rey, onder wie hy in Wes-Transvaal geveg het, Jaap van Deventer, Steyn, Hertzog en ook Botha.

Die Memoirs of General Ben Bouwer is vertel aan en geskryf deur mnr P. J. le Riche. Die redigering van die teks, toevoeging van historiese nota en die Inleiding is deur dr O. J. O. Ferreira gehanteer.

\section{W. OTTO}

\section{A Subject Bibliography of the Second World War: Books in English 1939-1974 by A.G.S. Enser London: Andre Deutsch, 1977 592p.}

A vast number of books have already been published on the Second World War and the publication explosion on this subject has still not been exhausted as can be seen from the continuous flood of new titles which appear almost daily.

This bibliography endeavours to provide in the need for gaining access to these books by listing books on the subject, written in English and published all over the world, from the beginning of the war to the end of 1974 .

The entries are arranged under subject headings in alphabetical order, eg African Forces, Afrika Korps, Agriculture, Airborne Forces. Full bibliographical information is provided for each item and an author index is included for cross reference.

\section{Bibliographic Guide to the Two World Wars: An annotated survey of English- language Reference Materials by Gwyn M. Bayliss. London: Bowker, 1977}

An enormous quantity of material has been published on the First and Second World War. Dr Bayliss has compiled this bibliographic guide as an aid to researchers and has listed and critically discussed over 2400 bibliographies and reference works to sources on this subject. 